\title{
An octopus-like obsession with loyalty
}

\section{American Science in an Age of Anxiety: Scientists, Anticommunism, and the Cold War by Jessica Wang \\ University of North Carolina Press: 1999. 375 pp. \$49.95, £37.50 (hbk), \$19.95,

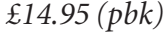 \\ Daniel J.Kevles}

In 1946, John and Hildred Blewett were invited to join the staff of the new Brookhaven Laboratory. Both were physicists who had worked on secret projects during the Second World War but, even though they would be engaged in unclassified research, their employment at Brookhaven required security clearance. The Federal Bureau of Investigation (FBI) questioned the Blewetts extensively about their politics and associations. David Lillienthal, a member of the Atomic Energy Commission (AEC), confided to his diary on hearing of the Blewetts' plight, "... the fact that ten years ago a scientist contributed to the defense of the Scottsboro boys, or believes in collective bargaining or the international control of atomic energy - such things as these are solemnly reported and regarded as 'derogatory information'."

The Blewetts ultimately got a hearing, and the AEC authorized them to work at Brookhaven on an uncleared basis. Even that limited disposition of their case had required the intervention of influential friends and taken seven months, and during that time they were reduced to living virtually on charity.

The Blewetts' story is only one of several harrowing encounters between scientists and the postwar national-security apparatus described by Jessica Wang, a historian at the University of California in Los Angeles, in her informative and eye-opening American Science in an Age of Anxiety. Some stories, like the Blewetts' ordeal, comprised sub rosa controversies fought in the shadowy interleavings of the FBI, academic and industrial contractors and AEC loyalty boards. Others involved bitter public confrontations between the House Un-American Activities Committee (HUAC) and politically leftleaning scientists, including, notably, the physicist Edward U. Condon, when he headed the National Bureau of Standards.

Covering mainly 1945-50, Wang's probing account of these episodes surpasses most others, since she draws on numerous public and private sources, including FBI records she obtained through the Freedom of Information Act. Her book is a graphic and disturbing analysis of how scientists became caught up in the octopus-like obsession with loyalty and security that pervaded American

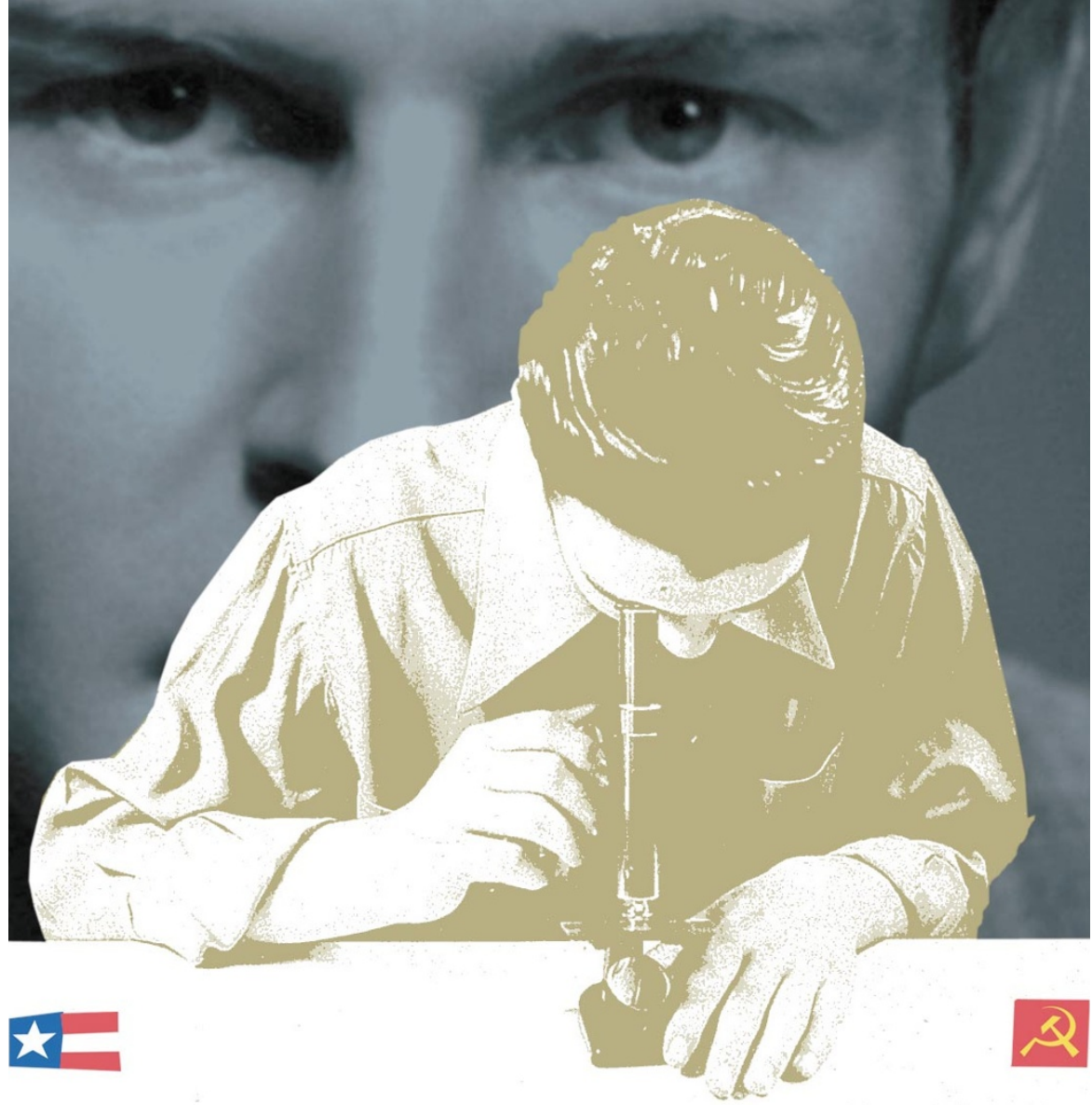

life in the early years of the Cold War.

Yet Wang marshals her hard-won evidence in service of a larger political story characteristic of the United States at the beginning of the Cold War: how the tentacles of the octopus squeezed much of the life out of left-leaning activism in the politics of postwar policy-making, in this case for science.

Wang reminds us that, immediately after the Second World War, postwar science policy, especially in the nuclear arena, was vigorously contested. Key members of the wartime scientific leadership, like the conservatively inclined Vannevar Bush, advanced proposals for an AEC that would have been dominated by the military and, like Bush's proposed National Science Foundation, insulated from direct democratic control. But a number of scientists, many of them on the liberal left, fought openly for a civilian-controlled AEC responsive to the democratic political system. More generally, they battled for international scientific cooperation in atomic energy and a science policy responsive to social needs. These initiatives gave rise to numerous local scientific political action groups that soon joined together in the Federation of American Scientists (FAS).

Wang demonstrates that the growing absorption with keeping atomic secrets incited attacks against these groups from conservatives, and surveillance by the FBI. The bureau monitored FAS chapter members and obtained information on chapter activities using informants. Its agents in turn fingered suspect chapter staff to selected FAS officers, who removed some of them from the staff to discourage red-baiting of the organization.

The assaults of the HUAC were energized in part by its ranking Republican member, Congressman J. Parnell Thomas, who was convinced that a civilian-controlled AEC would be security-loose. Politically savvy scientists took the HUAC's condemnation of Condon, an outspoken advocate of scientific cooperation with the Soviets, to mean that Thomas intended to reclaim atomic energy for the military.

Wang, with supple understanding of the relationship of executive agencies to congressional committees, points out that the Joint Committee on Atomic Energy was eager to protect the AEC from Thomas's attacks. However, Senator Bourke Hickenlooper, an Iowa Republican and head of the joint committee, pressured the AEC to forestall Thomas by tightening its security procedures. As far as Hickenlooper was 
concerned, only those beyond all suspicion should be granted clearance, regardless of the rights of suspects. Lillienthal, beleaguered, flawed, but understanding the stakes better than most, wrote in his diary that he would be "God damned if I would start lynching these poor devils just because Hickenlooper or anyone else didn't have the backbone to insist on decency in these things".

The FAS intervened on behalf of individual scientists facing clearance difficulties. It also lobbied the AEC to establish fair rules and procedures for dealing with security cases, holding that in practice the agency's security operations were often subversive of individuals' rights. Wang notes that, while the procedures improved, suspect scientists remained disadvantaged by having to deal with hearsay evidence about, for example, their associations, relatives and reading matter. The American Association for the Advancement of Science, the National Academy of Sciences and the FAS each attempted to forge a position on the threat posed byloyalty and security procedures to civil liberties. But in the end, Wang shows, each did little more than advance tepid recommendations for procedural reforms.

Using the records of the National Academy of Sciences and other documentary sources, Wang gives a remarkable account of the academy's refusal to take a strong public stand in defending Condon against the defamatory methods of the HUAC. She also

\section{Rainbow reptiles}

All the colours of the rainbow are to be found among the world's reptiles and amphibians, judging by a stunning portfolio of pictures of 91 species by the Japanese photographer Ryu Uchiyama (Reptiles and Amphibians, Chronicle, illuminates the controversy that arose when, in 1949, the AEC wanted all its fellowship holders to sign a loyalty oath and a noncommunist affidavit. The academy, whose National Research Council selected the fellows for the AEC, accepted the ruling; but when, in the summer, the Senate mandated that all recipients of AEC fellowships undergo FBI investigations, the academy drew the line, forcing the AEC to compromise.

According to Wang, the loyalty and security procedures established by the Truman administration helped prepare the way for McCarthyism in science. This included applying political criteria in decisions on research grants, requiring loyalty oaths for members of university faculties, and denying passports to suspect Americans such as Linus Pauling and visas to suspect foreigners such as Paul Dirac.

Wang seems at times to push her case too far. She claims, for example, that, together with its anticommunist justifications, Truman's loyalty programme even "validated the more extreme actions of HUAC and, later on, Senator McCarthy". Nevertheless, her overall thesis is convincing: with their increasing focus on loyalty procedures, groups ranging from the FAS to the National Academy of Sciences avoided public or even internal discussion of the 'real questions' of what constituted loyalty in a democratic state. They thus permitted clouds of disloyalty to hang over politically progressive dis-

$\$ 12.95, \mathfrak{E 8 . 9 9 )}$. The New Caledonian giant crested gecko, Rhacodactylus ciliatus (below), can vary in colour from brown and yellow to blue. It lives in trees and was thought to be extinct for more than 100 years, until it was rediscovered in 1994.

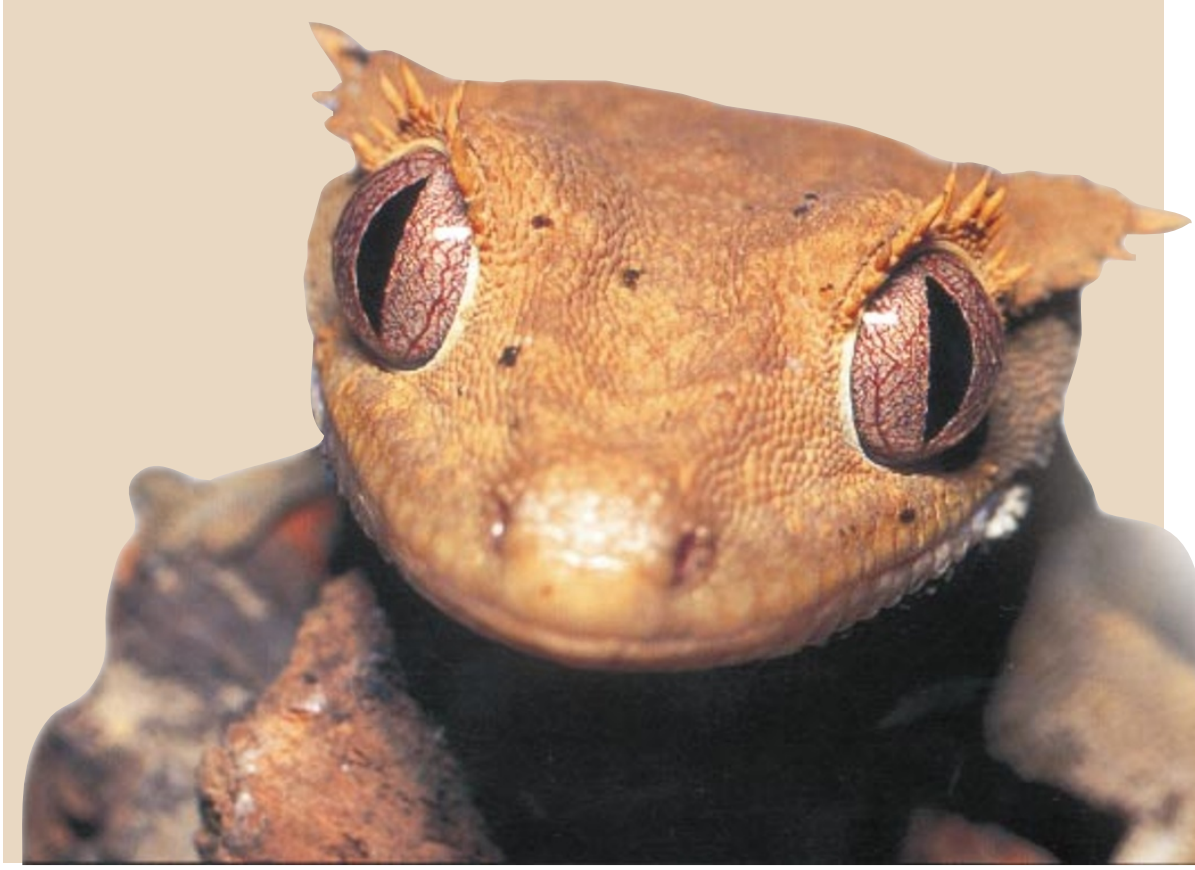

senters and contributed to the discrediting not only of them but also of their ideas.

Daniel J. Kevles is in the Division of the

Humanities and Social Sciences, California Institute of Technology, Pasadena, California 91125, USA.

\section{Beware the diseases of the will, my child}

\section{Advice for a Young Investigator}

by Santiago Ramón y Cajal, translated by

Neely Swanson and Larry W. Swanson

MIT Press: 1999.176 pp. $\$ 22.50, \mathfrak{£} 15.50$

\section{Pere Puigdomènech}

Science as a career has never been an easy choice for a young person. For centuries it was the domain of philosophers and the enlightened rich; it only became a job at the turn of this century. Now, when unemployment and underemployment have become commonplace for young postdocs, how is it possible to envisage science as a choice? It may seem surprising to seek the advice of someone who wrote about this question a century ago, but the author is Santiago Ramón y Cajal, in many respects a unique personality in science.

The son of a country doctor, Cajal (1852-1932) was born in a little village in the north of Spain. He trained as a doctor himself and saw military service as a medical officer in the Cuban War of Independence before becoming professor of histology at several Spanish universities and developing a deep interest in the study of nerve cells. A critical and passionate writer, Cajal was so precise in his work that his drawings are still used in present-day publications and he remains one of the most cited authors of the life sciences. He was awarded the Nobel prize for medicine in 1906, and to this day is the only Spanish scientist to receive the prize for work done in his own country. He was active in promoting science, serving for more than 20 years as president of the Junta de Ampliacion de Estudios, one of the first European institutions designed to promote the education of young scientists by helping students to travel and carry out experiments.

Cajal's Advice for a Young Investigator includes chapters on the qualities needed to become a scientist, the problems the young investigator may encounter and the way to write scientific papers. The book's curious subtitle in Spanish — The Tonics of Will — is very typical of this author's ideas. The will is, according to Cajal, the main feature that the young scientist has to cultivate.

One hundred years after this book was written, it evokes mixed feelings. On the one hand, most of the advice and comments on the practice of science are perfectly valid 